\title{
GIANTISM AND BASING-POINTS: A POLITICAL ANALYSIS*
}

\author{
EARL LATHAM†
}

The Cement case of April 1948 deals with the central problem of politics - the organization, administration, and control of power. On the surface, the case deals with basing-point prices, and the order of the Federal Trade Commission in the case requires the Cement Institute to cease and desist from conspiring to eliminate competition through private price controls in the marketing of cement. Struggles over prices, however, are struggles for security and advantage, and for the power that is at stake if prices move up or down. In the Cement case, prices were determined by formulas which left customers no price basis for choosing between one producer as against another. Price control was central to the maintenance of what may be described as a security system, operated for the benefit of the members of the Cement Institute. Although uniformity of prices is theoretically consistent with either free competition or monopolistic restraint, ${ }^{1}$ the Commission found that the latter was both the object and the necessary result of the Cement Institute conspiracy. As one of the Institute's trustees put it in a moment of friendly candor to a colleague in the cement industry:

"The truth is of course-and there can be no serious, respectable discussion of our case unless this is acknowledged-that ours is an industry above all others that cannot stand free competition. that must systematically restrain competition or be ruined. . . ." a

*The analysis of this paper is based upon the following political propositions: (1) the principal social values of modern life are realized through group action; (2) groups organize for security and advantage, to control the environment in which they esist, in order to make it predictable and safe; (3) organization begets counter-organization; (4) coalitions, constellations, and combinations of groups struggle with each other for security and the advantage of their members; (5) the struggle takes place in the official as well as the private fields of controversy; (6) the distinction between "official" and "private" is the social understanding that the first have the right to give known and knowable orders to the second; $(7)$ in the struggle for security and advantage, private groups enlist the support of official groups in their behalf when the added leverage of official power is required; ( 8 ) a principal function of legislators is to referee the group struggle, to ratify the victories of successful coalitions, and to record the terms that define the compromises, surrenders and victories in the form of statutes; (9) legislative votes tend to represent the composition of strength, i.e., the balance of power, among the contending coalitions at the moment of voting; (10) what may be called "public policy" is the equilibrium reached at any moment in the struggle of contending coalitions, an equilibrium which factions of groups constantly strive to weight in their favor.

† Joseph B. Eastman Professor of Political Science; Chairman, Department of Political Science, Amherst College.

1. The Cement Institute et al., 37 F.T.C. 87, 251 (1943).

2. Id. at 144 . 
Before the Supreme Court decision in April 1948, the Cement Institute was a private government organized to protect an economic security system. As such it became a goal of several official groups which exist or have existed to divert the force of such private governments away from socially unacceptable objects. Among these groups are the Federal Trade Commission, the lower federal courts and the Supreme Court, the Departments of Commerce and Justice, the Temporary National Economic Committee and the House Select Committee on Small Business. Although possessed of the advantage of officiality, these agencies have suffered from grave weakness in dealing with organized structures like the Cement Institute. Industrial groups possess unity of command and community of purpose and interest. They can be deployed in full vigor against the separated agencies and branches of officialdom, which are often at war with each other. At no time have all of the resources of formal government been fully coordinated in a single striking force against the concentrations of monopoly power organized in the many systems of private government that inhabit the economy. Either Congress has failed to give the Department of Justice sufficient appropriations, or judges have countermanded Commission orders, or committees have made solemn recommendations which have gone unheeded by Congressmen and Presidents. It took over ten years before the Commission and the Supreme Court succeeded in combining their forces to declare the cement combination unlawful.

The Cement case of 1948 is a. stage in the struggle of monopoly to dominate and exploit its environment for the security and advantage of its members. The Supreme Court decision represents a temporary victory of official power over a centrally organized system of private government. The struggle is continuous and will not end with the Supreme Court decision. In fact the Supreme Court decision may be regarded most clearly as only one level of compromise in a never ending series of compromises and adaptations, armistices and adjustments. Immediately after the Cement case the cement and steel industries began to rally fresh groups to their support to revise or overrule the Supreme Court decision.

This essay will concern the political nature of the Cement Institute, some aspects of the politics of revision, and the control of concentrations of private power.

\section{The Politics of Basing Points}

\section{The Cement Confederation}

A system of private government, the Cement Institute in organization and structure most closely resembled a confederation. It was a union of virtually all of the manufacturers of cement in the United 
States. Constituent corporations were semi-autonomous in the management of their respective enterprises. But they were limited in their choice of business policies by their compliance, willing or forced, with the rules administered by the central organization in behalf of all. ${ }^{3}$ The central organization of the confederation had its officers, trustees, committees, divisions, bureaus and other agents, including field representatives-all performing governmental functions. ${ }^{4}$

The executive authority was vested in the president, vice-president and treasurer, and the legislative authority was vested in the trustees. Taxes were laid on the members of the confederation by the central body, and each member had to continue these payments for a year after resignation from the Institute. ${ }^{5}$ This pecuniary penalty for withdrawal was one of the methods used to keep the confederation intact.

Like the federal union in the United States, the Cement Institute came into being only after inferior forms had been tried and found wanting. One of the earlier organizations-and later one of the largest sub-groups within the Institute-was the Portland Cement Association, known from 1902 until 1916 as the American Portland Cement Manufacturers. ${ }^{6}$ It was succeeded by the Cement Manufacturers Protective Association. The main function of this association was to compile and circulate statistics about costs, prices, freight rates and distribution channels. The U.S. Department of Justice decided that what the association was really trying to do was to control and make uniform the prices of cement. But the Supreme Court, in dismissing the Justice Department's suit, said there was insufficient evidence to that effect and that the Association had not succeeded in getting price uniformity. ${ }^{7}$ Apparently the cement industry was also well aware of this latter fact. The Cement Institute was organized in 1929 as a device for the more efficient control of the industry after the two previous arrangements had failed.

As the articles of association said, one of the purposes of the Institute was "[t]o adopt and promulgate a Code of Ethics for the government of its members . . . [and] to establish and maintain all such lawful trade customs and usages for the protection of the members as the Institute may deem advisable." ${ }^{8}$ In 1933, this private government was given virtually official status when the Trade Practice Committee of the Cement Institute became the Code Authority for the industry under

\footnotetext{
3. A principal method of coercion was economic loss. Sce 37 F.T.C. 179 (1943).

4. Id. at 125 .

5. Id. at 126 .

6. Id. at 143 .

7. Cement Manufacturers' Protective Association v. United States, 268 U.S. 589 (1925).

8. 37 F.T.C. 87,157 (1943).
} 
the NIRA. ${ }^{9}$ When the NIRA was invalidated in the Schechter case of 1935, the Trade Practice Committee for seven months thereafter continued to administer some of the provisions of the Code.

The relative ease in transition, from private to public status and back again, illustrates the purely formal nature of the terms "official" and "unofficial." During the whole NRA period, for example, the multiple basing-point price system prevailed despite objections before the Consumers Advisory Board ${ }^{10}$ and despite the efforts of state and federal agencies to purchase f.o.b. ${ }^{11}$ The basing-point system prevailed before and after NRA as well. But it was only one of many devices employed by the cement industry to establish a security system.

\section{Devices of Control}

Cement has been manufactured in the United States for a period of some seventy years, having been imported before that time. With the appearance of the industry, the movement for control soon followed. Three principal control devices have been utilized for the purpose of producing uniformity of price-patent control, dissemination of price and cost data, and the administration of a formulary price system through the Cement Institute. The use of these principal methods of control correspond with fairly well defined periods in the history of the industry. The patent control period lasted from 1900 to 1911. Two employees of the Atlas Portland Cement Company, the Messrs. Hurry and Seaman, secured a patent on a method of burning powdered coal in rotary cement kilns. ${ }^{12}$ From this beginning there developed a system of price manipulation through licensing agreements which collapsed in 1911 after a court decision adverse to the validity of the Hurry and Seaman patents. The next principal method of control was the dissemination of statistical information through the Cement Manufacturers Protective Association. As indicated previously, this was not enough to keep everyone in line.

The third and most effective system of control was that applied by the Cement Institute. The focal point of control was multiple basingpoint pricing. Under this system, sixty basing-points were established in the United States, each with its base price for cement. In calculating the delivered price for cement for any customer, the seller had first to decide which basing-point governed. This was done by adding to the price maintained at all basing-points near the customer, the all-freight rail charge from each of the basing-points to the customer. The smallest sum of these factors (basing-point price plus rail charge) was the
9. Id. at 159 .
10. Id. at 158 .
11. Id. at 160 .
12. Id. at 153 . 
price at which any producer would sell to the customer. Every seller of cement in the United States would sell to a given customer, therefore, at the same price.

In order to enable any seller to make this simple arithmetical calculation it was necessary for all of them to know the location of the basingpoints, the basing-point prices, and the freight rates. ${ }^{13}$ The information as to freight rates was supplied by the freight bureau of the Cement Institute in the form of freight rate books. These rates are fixed by the Interstate Commerce Commission and by state regulatory bodies, and are distressingly complex. Control of the location of basing-points and of the basing-point prices was in the hands of the Institute, but control of the basic freight rates was not. In cases of conflict between the published rates of the ICC and those set out in the freight rate books distributed by the Institute the members of the industry were disciplined to conform to the Institute's figures. When the ICC, for example, changed a rate, the members of the cement industry continued to calculate their delivered prices at the old freight rates until they were told by the Institute that they could calculate them at the new rates. ${ }^{14}$ They were permitted to calculate them at the new rates when the Cement Institute had had time to prepare its new rate books. Thus the edict of private authority superseded that of public authority in an area where the latter was presumed to possess overriding control. It was in effect an arrogation by the Cement Institute to itself of the power of public authority to determine the rules by which industry was to be governed. It is an especially good example of what Beardsley Ruml describes as the rule-making function of private business groups. But it takes more than promulgation to make a rule stick. The Cement Institute had to indulge in a wide variety of activities to make the industry secure.

\section{Security by Force}

The most obvious aspect of the security system was the multiple basing-point delivered price. But as in the execution of its programs and policies by public government, the system of private government represented by the Cement Institute had to devise and administer numerous corollary, supporting, and protective activities to perfect the central point of control. Divisionist influences had to be fought off so that the members of the confederation might continue to exist in domestic tranquillity and non-competitive amity. The Cement Institute lived in an environment of groups potentially hostile to it and to the basing-point system. Security in this environment made it necessary to neutralize these outside pressures. Among the potentially

13. Id. at 103.

14. Id. at 109. 
hostile groups in the universe in which the Cement Institute dwelt were truckers, dealers, customers, foreign importers, and state and federal agencies.

Truckers. Customers frequently would want to truck their cement from the plant of the manufacturer to destination. Such a practice breaks the basing-point formula by changing the freight rate factor. In fact, if the buyer were permitted to take delivery at the mill and transport by truck, the seller lost control of the delivered price. ${ }^{15}$ After an initial period of some ten years after the First World War, during which the cement industry tolerated a certain amount of such buying, the industry, by cooperation, understandings and agreements among themselves began systematically to discourage the practice. It is interesting that this policy coincided with the appearance of the Cement Institute and is another indication that the Institute was a superior form of private government, much more efficient than the arrangements that had previously existed, for protecting the security system of the cement manufacturers. Various restrictive steps were taken to discourage trucking by customers, including the imposition of penalties in the form of a fifteen cents a barrel surcharge paid only by those asking delivery to trucks. ${ }^{16}$ There were several regional variations of the penalty price discrimination. ${ }^{17}$ By 1932 a major part of the cement manufacturing industry had declined to permit trucking under any circumstances, and most of the rest forced buyers to pay penalty prices for delivery by trucks. ${ }^{18}$

Dealers. A second group of potential hostiles in the environment of the cement manufacturers was the body of dealers, who purchase a substantial percentage of all cement sold. ${ }^{19}$ Irregularities (in price or otherwise) in the sale of cement by dealers tended to disturb the security system of the cement manufacturers, and various policies were employed to neutralize this dangerous influence. Before 1913 no discounts were given to dealers by Lehigh, one of the principal producers of cement, but for the next eighteen years some form of dealer differential was maintained. ${ }^{20}$ Eventually the discount was ten cents a barrel. It proved to be a source of weakness in the security system of the manufacturers. Some dealers, for example, in order to get attractive carload business, sold to consumers on a five cents margin. They were

15. Id. at 191.

16. Id. at 192 .

17. Id. at 193.

18. Id. at 198. Although the manufacturers combined to prevent customers from tak* ing delivery f.o.b. trucks, the manufacturers frequently employed trucks for delivery whilo charging the all-rail freight rate. $I d$. at 114 .

19. Id. at 141.

20. Id. at 226. 
thus able to quote the manufacturer's product to the consumer at less than the manufacturer's price to the consumer. ${ }^{21}$

The Institute therefore abandoned the trade discount to dealers but then found it necessary to devise other methods for controlling the competition between dealers and manufacturers and among dealers. This was done by making the dealers the exclusive outlets for cement in dealer markets, with certain exceptions. Manufacturers reserved the right to sell directly to the federal and state governments, railroads, and certain users employing cement for the manufacture of cement products, but not for resale in bulk. ${ }^{22}$ This rationalization of the market was written into the Code for the Cement Industry in 1933, but it was set aside in 1934. Defeated in the attempt to write these restrictions into law, the Institute reached the same result by declarations of policy to which the customers of cement were expected to adapt themselves. That they did so is shown by the correspondence gathered by the Federal Trade Commission from the National Federation of Building Supply Associations, Southwestern Lumbermen's Association, Nebraska Lumber Merchants Association, and the Mountain States Lumber Dealers Association. ${ }^{23}$ Arrangements vere also made to maintain uniform compliance with the new policy by the designation of a "contact" man between the Institute and the National Federation of Building Supply Associations to police the new rule and to report violations of it. ${ }^{24}$ This is a good example of the manner in which the Cement Institute as a system of private government put into effect a rule of conduct which not only differed from the rule of public authorities but violated it.

The Dealer Policy of 1935 reserved to the manufacturer the right to make sales to the Federal Government but the right was not preclusive. In fact the dealers were made the exclusive channel for sales to unemployment and relief agencies like the Works Progress Administration, Civilian Conservation Corps, and Federal Emergency Relief Administration. All sales through dealers carried the dealer's mark-up. The result was a tax imposed upon the people of the country by the Cement Institute for the benefit of the dealers and the maintenance of the cement manufacturers' security system..$^{25}$

Customers. A third, and the most numerous, group dwelling in the environment of the cement confederation was the heterogeneous group of customers. Since their behavior as customers could threaten the security system with disorder, it was thought necessary to organize, classify, and rationalize this behavior. It had to be made safe and

21. Id. at 227 .

22. Id. at 228 .

23. Id. at 230 .

24. Id. at 231 .

25. Id. at 232-3. 
predictable to the confederation. Many strategems were employed to accomplish this object. Customers, motivated by the same desire for security and advantage as the Institute and its members, sought to free themselves from the iron grip of a rigid price system by making long-term contracts with dealers at the price determined at the time of the contract. The purpose of these contracts was to insure the customer against increases in price decreed by the manufacturers. In effect it was an engagement by dealers to absorb such increases in return for the advantage of a long-term order. A variation of this practice was for customers to order cement from a number of sources for the same job, stockpiling this commodity as an insurance against price increases. ${ }^{26}$ The Institute met this subterfuge by collecting and disseminating information about specific job contracts. This information quickly showed which customers were placing orders beyond the needs of specific jobs on hand, both in quantity and length of contract. ${ }^{27}$

The Institute did not leave it to the individual action of its members to control this practice, however. Collective action and the pressure of collective opinion were brought to bear upon members of the Institute to cancel the contracts violating or threatening the security system. ${ }^{23}$ In all of this politicking, the Institute took pains to make it appear that the checking and cancelling of contracts was a matter of individual action. ${ }^{29}$ For example, the Institute supplied daily summaries of contracts and cancellations to the members of the Institute, but declined to send such information directly to the field representatives of members of the Institute. The Institute in a letter to one of its members explained this refusal on the ground that it wanted to avoid "the implication that the Cement Institute has any authority in the control of contract obligations." 30

Customers also evolved a method of evading quoted delivered prices. If the quoted price to a point beyond the customer's own location was higher by an amount less than actual freight, he would order the cement to be delivered to the more distant point. Then while the goods were in transit, the customer would have them diverted to the proper destination. The freight charge would be less than that assumed in the manufacturer's quoted price, and the customer would thus save at the seller's expense. By means of understandings and agreements, the Institute sought to prevent purchasers from engaging in this highly "unethical" practice of diversion in transit. ${ }^{31}$

The practice of diversion was castigated in the Code for the Cement
26. Id. at 202.
27. Id. at 203.
28. Id. at 204.
29. Id. at 206.
30. Ibid.
31. Id. at 199. 
Industry in 1933 as an unfair trade practice. It had previously been asserted to be a venal practice in the Code of Ethics adopted by the cement manufacturers when the Cement Institute was established in 1929. After the expiration of the NIRA, the trustees of the Institute drew up a "Compendium of Established Terms and Marketing Methods" which also characterized the diversion of freight as an unfair method of competition. The Compendium recommended the use of a standard contract form which required the purchaser to pay the full original price if the freight were diverted in transit.

In disciplining and chastising purchasers of cement, the Cement Institute was able to enlist the cooperation of the railroads. The traffic advisory committee of the Association of American Railroads was induced to recommend to its members that they accept bills of lading stamped with a clause prohibiting diversion. These bills of lading were used by many of the members of the Institute. ${ }^{32}$ After 1937, the members of the Institute began to pre-pay the freight charges for cement. As the Federal Trade Commission concluded, "When freight is prepaid, there can be no diversion of shipments by the consignee to his advantage in price." 33

Official agencies. A fourth group constituting a threat to the security system of the cement manufacturers was the complex of federal and state purchasing agencies. There is no evidence that the members of the Cement Institute at any time were impressed by the character of federal and state agencies as organs of government, possessors in some small part of the sovereign power of the people, the supreme political power of an organized community. The evidence tends rather to show that the members of the Cement Institute regarded agencies of the federal and state governments as just another group of individuals, not too scrupulous, seized of certain unfair privileges in dealing with non-official groups, a fat source of profit, but not entitled to any better treatment from the members of the Institute than any other customer, and certainly not entitled to preferences merely because they happened to be serving public policy for the whole nation. The Institute insisted on treating the members of governmental agencies like all customers in the grip of the confederation, but complained loudly when the members of the Institute were treated by governmental agencies on the same cold-blooded basis of profit.

For example, as part of its policy to fix high prices and to ration low production, the cement confederation undertook to discourage the entry of new producers into the cement industry. When the Tennessee Valley Authority was established, it required millions of barrels of cement for construction work. It called for bids on cement and re-

32. Id. at 201.

33. Id. at 202. 
ceived such bids from members of the Cement Institute, all of them substantially identical. Thereupon TVA made a study to determine the practicability of building and operating its own cement plant. Representations were made to the TVA by members and officers of the Institute, after which the TVA decided to make a joint examination of costs to determine a fair price for cement. It also decided that if bids received were not reasonable in terms of these findings, it would make some move to build its own plants. The threat, accompanied by an ultimatum, guarded but firm, produced the desired result. A compromise price was agreed upon and TVA purchased its cement. ${ }^{34}$

Although the Institute had no qualms about charging a monopoly price, and no scruple about insisting that the TVA "take it or leave it," it was with the sharpest cries of pain and self-pity that it received the TVA ultimatum. In a long, ill-tempered telegram to the Chairman of TVA, one of the trustees of the Institute employed such phrases as "prejudice against businessmen," "to coerce the companies," "arbitrary power," "immense power," "control of vast government funds," "ruthless declaration," "arbitrary determination," "under threat of dire punishment," and so on. ${ }^{35}$ The Cement Institute was not a happy contributor to the reconstruction of the Tennessee Valley.

The somewhat cynical conception of governmental agencies as a group of enterprisers to be overreached if possible, was implicit in the classification and division of customers between manufacturers and dealers, of which note has already been made. When the dealer arrangement was established as an Institute policy, it was thought to be desirable to maintain close liaison with federal purchasing officials to make sure that the Institute view was properly presented. The representatives of the Cement Institute did their work well and persuaded the military men who were in the Procurement Division that it was in the public interest to buy through dealers at a higher price than by direct purchase from manufacturers at a lower price. ${ }^{30}$ The secretary of the National Federation of Builders Supply Associations was jubilant over the victory as he confided in a letter of August 28, 1935:

"There were those who said 'it couldn't be done.' To them it seemed a hopeless task to buck a Department of the Government which was determined to buy direct. However it has been done and, in my judgment, it is conservative to say that in excess of $\$ 50,000,000$ of business will be held in dealer channels which . . . would certainly have gone direct.

"Instead of disaster which seemed to be certainly headed in our direction, we have been able to gain a signal victory. We have

34. Id. at $223-5$.

35. Id. at 224 .

36. Id. at 233. 
proved to the Government, to manufacturers, and to ourselves that we are alive and willing to fight for our rights. More than 10,000 communications went into Washington, I am informed, either directly to members of Congress or to the Procurement Division. ..." 37

This "signal victory" helped to swell the cost of government about which business groups as taxpayers are so solicitous.

In the struggle to overreach governmental agencies, one situation continued to baffle the Cement Institute. This was the method of making bids for federal purchases of cement to be carried over railroads to which the Federal Government paid land-grant rates. The now-extinct land-grant rates were less than ICC rates, and were not published. The basing-point delivered price formula employed by the members of the Cement Institute required for its successful operation an exact knowledge of the freight rates between basing-points and any point of destination. Since the rates that govern the carrying of federal freight under the land grant discount were not generally known, one indispensable element of the pricing formula was missing.

Under the Code for the Cement Industry, members of the Cement Institute filed destination prices with the Code Authority which were then disseminated. It was then possible for each of the member companies to know in advance what each of his fellow members would charge the Federal Government so that it was possible to achieve uniformity in the bidding, even though the bids did not represent the calculation that might have been made had the freight rates been known. After the abolition of the Codes, the Institute began a systematic search for land-grant rates, a search akin to the espionage activities familiar in foreign relations, with a vigorous underground and a central intelligence headquarters. The Cement Institute sought to piece together information about land-grant rates from a variety of sourcesthe railroads themselves, previous lettings, and from competitors. ${ }^{23}$ The search was given up after a year or so of operation, and the problem of land-grant rates continued to be a baffling one..$^{3^{\circ}}$

Strangers. New domestic producers and importations of foreign cement constituted a fifth threat to the security system of the cement industry. Attacks were therefore made upon new producers and upon foreign importations of cement. The Code for the Cement Industry in 1933 contained a provision permitting the Institute to petition the President of the United States to prohibit the establishment of new plants, increases in the capacity of existing plants, and even the moving of an existing plant from one location to another. ${ }^{43}$ The hostility to

37. Id. at 234 .

3S. Id. at $16 \mathrm{~S}$.

39. Id. at 173 .

40. Id. at 219. 
increases of production that would disturb the security system of the existing members of the Institute led it to protest the granting of loans by the Reconstruction Finance Corporation to units of industries already in a state of excess capacity of production. ${ }^{41}$ The strategy of opposition to this "harmful practice" of the RFC, as it was called, included the use by private persons of the letter-head of the NRA Code Authority for the Cement Industry, ${ }^{42}$ the solicitation of letters of protest, and help to a writer for the Chicago Herald and Examiner in the preparation of an article in support of the cement industry, titled, "Wasted Taxes." 43 In view of the Institute's insistence that agencies of the Federal Government pay the dealers' mark-up for cement, the Institute was in a position to counsel the newspaper writer with an expert knowledge of his subject. The plant which was the particular object of the Institute's attention was not put into operation, although the Institute, in other respects, was not always as successful in crushing incipient competition. ${ }^{44}$

Different situations called for different methods in repelling the appearance of new groups threatening the security system, and in defeating those who managed to gain entry. The appearance of imported cement in the American market was the signal for concerted attacks upon dealers and others who handled it. The industry utilized the techniques of espionage, encirclement, systematic price undercutting, boycotts, and reprisals. ${ }^{45}$

\section{Security by Propaganda}

Like public governments, and like many other systems of private government, the cement confederation maintained a ministry of information and propaganda, a Committee on Public Relations. When the price of cement went up in 1933 in the face of continuing depression, there were many protests against the cement industry from both public and private sources. ${ }^{46}$ The Institute and its members thereupon engaged in a concerted and systematic campaign of propaganda to allay the criticism and put to sleep the hostility. This was difficult, as some of the members of the Institute admitted, because it was hard to defend the industry without defending its most characteristic policy - that competition should be stifled. The sense of grievance that the industry should be required to defend itself is manifest in the comments that a midwestern governor had acted in "a rather unfriendly and un-
41. Id. at 220 .
42. Ibid.
43. Id. at 222.
44. Id. at 223.
45. Id. at 235-6.
46. Id. at 239 . 
justified manner"; ${ }^{47}$ that certain editors "who should be friendly feel that we are gouging"; 43 and that the "cement business is in public disfavor." To counteract this public disfavor, to neutralize the growing acidity of the environment which it had to keep bland, the Institute put on a campaign with the usual appurtenances of a promotional drive familiar in the advertising world. ${ }^{49}$

One aspect of this campaign is especially noteworthy because it exhibits a cold political calculation of the strength of the opposition to be quieted or appeased. This was a table of the "Approximate Number of Leaders of Groups to be Convinced," of which twelve groups were listed. ${ }^{50}$ The first five groups covered officialdom and the press, as follows: (1) federal and state officials; (2) newspapers, magazines and journals, general and economic writers, financial editors and writers; (3) United States senators and representatives; (4) state senators and representatives; (5) county commissioners and engineers, mayors and city managers, and city engineers. The Institute calculated that the apparatus of the public government and the media of mass communications were the first and most important of the centers of potential resistance and hostility that had to be taken. The experience of underground movements in Europe would seem to confirm the shrewdness of this calculation.

Behind this first rank of five groups came seven others, representing the principal structures of interest in the immediate business milieu of the cement industry. These were (1) building materials dealers; (2) civic leaders and financiers; (3) contractors; (4) manufacturers of concrete products; (5) civil engineers and architects; (6) cooperating organizations; and (7) other industries, like the steel industry, having the common problem of basing-points and monopolies to defend. These tables of the organization of the opposition listed the number of leaders to be persuaded over to the side of the cement industry. The entire calculation is of interest politically, because it is based on the assumption that the significant political form is the group, and that within the group there is a leader-follower relation which can be exploited. Capture the leaders and the followers will not be troublesome.

\section{Creating Internal Unity}

This analysis of the politics of the Cement Institute may be concluded with some brief observations about the devices used by the Institute to create and maintain a community of interest among the members. The elements of governance in private as well as public
47. Id. at 240 .
4s. Id. at 241 .
49. Id. at 244-5.
50. Id. at 246 . 
systems are constraint and consent. Community interest is cultivated by use of the carrot and the cudgel. Since consent is a perishable good, the managers of governmental systems must be able to count upon its constant renewal. If it is not constantly renewed as a by-product of policies that keep the constituent members happy, consent must be manufactured. The private government of the Cement Institute was aware of these problems of rulership and pursued courses pointing to the following objects: belief in the equality of the constituent members; belief in the existence of a community of interest among the members; and the development of a group morality.

Equality. The policies of the Cement Institute were designed to confront the customers with an industry in which there was no valid economic basis for choosing one manufacturer as against another. The Institute enforced this doctrine of equality by asserting the official line that cement was a fungible product, and that there were no substantial qualitative differences. To be sure there were grades of quality but no differences within these categories. ${ }^{51}$ The result of this policy was to destroy brand preferences and quality competition. The competition among the manufacturers took place on the level of social diversion. As the president of the Lone Star said, the scramble for business uses weapons "wrought from influences which have nothing to do with the product or the merits of the manufacturer's proposition." ${ }^{52}$ The claim that all portland cement is the same not only served as an instrument of price control but also served the political purpose of establishing a confederation of constituents of equal rank. Equality of rank in a confederation is not indispensable to its continued existence, but it helps.

Community of interest. Belief in the existence of a community of interest among the members was promoted by the assertion that the industry could not stand competition. Divided, all stood a chance of loss. United, all stood a chance of gain. The world which the Institute conjured for its members was one in which the cement industry was encircled by a ring of hostile groups. The security of the members consisted in their adherence to each other in a common front against this danger to their well being. This is the tactic familiar in the foreign policies of public governments, and is a well tested device for maintaining internal controls. The threat of foreign invasion goes far to convince the domestic members of a federation that they must stay together.

Group morality. The belief in a community of interest established a foundation for the development of a group morality, a pattern of right and wrong, a structure of values in behavior to insure survival. This

51. Id. at 237 .

52. Id. at 238 . 
morality was not necessarily the morality of the outgroup universe, since the outgroup universe did not assume the self-preservation of the ingroup as the highest goal, as the Cement Institute did. The internal code of morality was functionally connected with the preservation of the group. A "code of ethics" was created by the Institute shortly after its establishment in 1929, and this code became the basis of much of the NRA Code for the cement industry. When this occurred, the private code became the public law for the group, theoretically enforceable by public authority as well as by the discipline of the private group. When the NRA died, the Institute continued to exert control that was little less effective, until the FTC finally caught up with it in the Cement case of 1948.53 This setback turned the efforts of the cement industry-and of a host of enterprises similarly situated-toward revision of the troublesome antitrust laws.

\section{The Politics of Revision}

It had been no mean job for the Cement Institute to keep its security system from falling apart at the seams. It took vigilance, ingenuity and persistent effort to keep errant members in line and to counter the pressures of outside antagonists. Perhaps this is the main explanation for the dismay that greeted the adverse decision of the Supreme Court. For in banning concerted use of a basing-point price formula, the Court took away a practice that had become central to the whole security plan of the cement and other industries. Having found the Court an unfriendly forum, these industries commenced a fabulous campaign to revise the law itself.

The steel industry abandoned its basing-point system of pricing and moved to f.o.b. mill in July 1948. Viewed politically, this action was a move to create resentment among the customers of steel against the Federal Trade Commission, and thereby to organize a combination of disaffected groups capable of getting Congress to override the decision of the Supreme Court. This is a form of economic pressure, and therefore of power applied, to revise the law in favor of those who were defeated in the Supreme Court. The chorus of protest against the Cement case thus is made to appear to come from small customers of the big combinations, and not from the big combinations. So far as the big combinations are concerned, they are performing the highly moral act of complying with the law. The chief stage for the protesting chorus for eight months after the Cennent case was the United States Committee on Trade Policies, and the choirmaster was Senator Homer E. Capehart of Indiana.

In November and December 1948, the sub-committee heard over a hundred witnesses on the need for revising the basic law with respect

53. For a detailed analysis of the Cennent case of 1948 , see 53 Y 1 LE L. J. 426 infro. 
to pricing, as now interpreted by the Supreme Court. It seemed to be forgotten that the Court had done little more than outlaw a more or less obvious price-fixing combination. The major theme of the attack on the Cement case was sounded by the general counsel of the Senate Trade Policies Committee before the annual meeting of the Grocery Manufacturers of America. ${ }^{54}$ Congress, it was said, must determine the pricing system to be used by industry and clarify the law which is now confused: if the law means only that uniform delivered prices achieved by combination and conspiracy are outlawed, it was argued, there is no occasion for general concern in industry, but it is not now clear, however, whether freight absorption without conspiracy is unlawful. A host of witnesses marched past the Senate Trade Policies Committee voicing variations of this central theme. Among the groups and groups of groups making appearances were the Great Western Sugar Company of Denver, the Amalgamated Sugar Company of Odgen, Utah, Montana-Wyoming Beet Growers Association of Worland, Wyoming, United Cement, Lime and Gypsum Workers International Union, National Small Business Men's Association, Associated General Contractors of America, Bridgeport Brass Company, and other companies. Witnesses for these organizations are only a sample of the diversity of groups whose views were voiced. Even the principal supply officers of the Army and the Navy were brought forward to testify in favor of freight absorption and freight equalization arrangements. ${ }^{56}$ To add to the bustle of activity generated by the Cement case, the Commonwealth of Pennsylvania advertised the industrial advantages and virtues of Pennsylvania in case the f.o.b. mill pricing system makes "it necessary for you to have a plant in Pennsylvania." 56

The campaign is not likely to succeed. Yet the most significant aspect of the politics of revision is not the method employed by pressuring groups, but the strength of their position. Even if these private governments lose the battle over basing-points, the foundation for monopolistic security systems will still be there. The industries need only to find substitutes for the basing-point device, and as the Supreme Court has remarked: "There is no limit to human inventiveness in this field."

\section{The Control of Power}

This discussion of the governmental nature of organized private groups may have communicated some sense of the process involved in regulation of monopolies. The process is a never-ending one of thrust and parry among corporations, enforcement agencies, legislators and

54. N. Y. Times, Nov. 16,1948, p. 45 , col. 3.

55. N. Y. Times, Nov. 30, 1948, p. 41, col. 1.

56. N. Y. Times, Nov. 21, 1948, p. E7, col.1. 
courts. So far the struggle has not moved a great distance in favor of either regulators or the regulated.

While it cannot be concluded that monopoly is more widespread than in the past, neither can it be said that competition has gained. The antitrust laws have been effective largely in a negative sort of way. Aside from occasional dissolution of overgrown firms, antitrust policy has been principally designed to keep monopolistic combinations within bounds, and it has not always been successful in that. At any rate, tremendous concentrations of economic power still exist, and they are far from inactive. Some of our billion dollar corporations exceed many states in their power and breadth of control. They are systems of private government that operate within the territory of public government. But unlike public authority, they are beholden to no electorate and responsible to no constituency save their own. And no classical "free market" exists to conform their economic decisions to the dictates of general welfare.

One of our difficulties is that we have not had a consistent antitrust policy, or applied adequate sanctions. We have tended half-heartedly at some times and in full earnestness at other times to make the Populist antitrust policy effective. This policy hoped to "make little ones out of big ones," and was primarily anti-industrial in its bias and motivation. Moreover, it was conceived at a time when men thought they could reverse a development that was then only in its beginnings. The development is no longer in its beginnings. In its early formulation, the antitrust problem was regarded as a moral one. The trusts were to be busted because they were wicked and greedy, not because they were big. We have not succeeded in enforcing the prejudices of our grandfathers. We need to formulate a policy of our own. The form and color of that policy will depend upon the choices we make as to what we want to do. What we have to do can then more readily be determined.

In its essence the problem of controlling giantism in the economic community is a political one; that is, it concerns the control of power. But words alone do not control power. Power controls power and if control is to succeed, the force we exert must at least equal the force we oppose. We have not yet exerted a force equal to the force we say we oppose. This is because we, as a people, have not really decided that we mean seriously to oppose giantism. Giantism can be controlled when the people and their representatives make up their minds to control it. The disarmament of these private empires does not outspeed the invention of new economic weapons. We lack a clear resolution to meet private power with at least an equivalent measure of official power. Up to this time public officials have been overmatched in an unequal contest. 


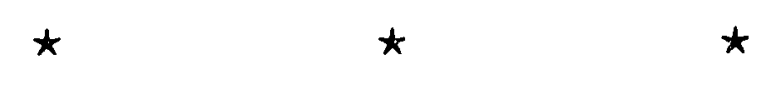

As an autonomous student publication, the YALE LAW Journal has traditionally sought to provide a medium for critical discussion on current legal issues. Recognizing that views may be as variant as writers, the JOURNAL has in the past on particularly controversial subjects endeavored to present differing opinions, not to choose among them. It was in this tradition that the JouRNAL undertook to treat the currently controversial subject of loyalty among government employees.

Accordingly, the JouRNaL arranged to publish a discussion of this problem by Messrs. Thomas I. Emerson and David M. Helfeld, and by General William J. Donovan. The Emerson-Helfeld article appeared in the December issue.

Before the planned treatment of the loyalty problem could be completed by publication of General Donovan's article, however, Mr. J. Edgar Hoover, Director of the Federal Bureau of Investigation, wrote to the editors of the JouRNaL, vigorously criticizing the opinions expressed by Messrs. Emerson and Helfeld. In view of the public significance of this statement by a government official directly concerned with the issue under debate, it is printed here in full, together with a reply by the original authors and a rejoinder by Mr. Hoover. The JourNal regrets that its publication deadline requires termination of the exchange at this point.

Insofar as Mr. Hoover's statement offers facts and opinions on the subject of loyalty among government employees, it is welcomed as a contribution to the process of free discussion upon which the JourNal must depend. Insofar as it suggests, however, that publication of the original article reflects partisanship on the part of the JouRNAL, or, on the other hand, that the partisanship ascribed to the article should have disqualified it from publication in the JourNAL, the editors must dissent.

The Editors

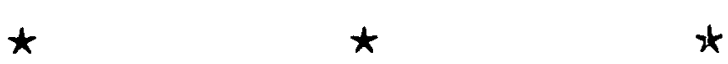

